\title{
Long term particle size distribution measurements at Mount Waliguan, a high-altitude site in inland China
}

\author{
N. Kivekäs ${ }^{1}$, J. Sun $^{2}$, M. Zhan ${ }^{2}$, V.-M. Kerminen ${ }^{1}$, A. Hyvärinen ${ }^{1}$, M. Komppula ${ }^{3}$, Y. Viisanen ${ }^{1}$, N. Hong ${ }^{4}$, Y. Zhang ${ }^{2}$, \\ M. Kulmala ${ }^{5}$, X.-C. Zhang $^{2}$, Deli-Geer ${ }^{4}$, and H. Lihavainen ${ }^{1}$ \\ ${ }^{1}$ Finnish Meteorological Institute, P.O. Box 503, 00101 Helsinki, Finland \\ ${ }^{2}$ Key Laboratory for Atmospheric Chemistry of CMA, Center for Atmosphere Watch and Services, Chinese Academy of \\ Meteorological Sciences, Beijing 100081, China \\ ${ }^{3}$ Finnish Meteorological Institute P.O. Box 1627, 70211 Kuopio, Finland \\ ${ }^{4}$ China GAW Baseline Observatory, Qinghai Meteorological Bureau, Xining 810001, China \\ ${ }^{5}$ University of Helsinki, Dept. Physical Sciences, P.O. Box 64, 00014 Univ. of Helsinki, Finland
}

Received: 13 October 2008 - Published in Atmos. Chem. Phys. Discuss.: 22 January 2009

Revised: 25 May 2009 - Accepted: 28 July 2009 - Published: 3 August 2009

\begin{abstract}
Particle number size distributions in size range $12-570 \mathrm{~nm}$ were measured continuously at Mount Waliguan, a remote mountain-top station in inland China. The station is located at the altitude of $3816 \mathrm{~m}$ a.s.l., and some 600 $1200 \mathrm{~m}$ above the surrounding area. The measurement period lasted from September 2005 to May 2007. The measurements were verified with independent CPC measurements at the same site. The average particle concentration in ambient conditions was $2030 \mathrm{~cm}^{-3}$, which is higher than the values measured at similar altitude in other regions of the world. On average, the Aitken mode contributed to roughly half of the particle number concentration. The concentrations were found to be higher during the summer than during the winter. The diurnal variation was also investigated and a clear pattern was found for the nucleation mode during all seasons, so that the nucleation mode particle concentration increased in the afternoon. The same pattern was visible in the Aitken mode during the summer, whereas the accumulation mode did not show any level of diurnal pattern during any season. Excluding the nucleation mode, the average day-time particle concentrations were not significantly higher than those measured at night-time, indicating no systematic pattern of change between planetary boundary layer conditions and free troposphere conditions. In air masses coming from east, the number concentration of particles was higher than in other air masses, which indicates that the air
\end{abstract}

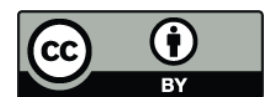

Correspondence to: N. Kivekäs (niku.kivekas@fmi.fi) mass might be affected anthropogenic pollution east of the station. Also other factors, such as active new-particle formation, keep aerosol number concentrations high in the area.

\section{Introduction}

In order to improve our understanding on the climatic and other influences of atmospheric aerosols, we need to have detailed information on the physical, chemical and optical properties of these aerosols (e.g. Diner et al., 2004). Since practically all aerosol properties vary greatly in both time and space, multiple approaches to tackle the problem are required. These include large-scale model simulations, usage of various remote sensing techniques and in situ measurements (e.g. Yu et al., 2006; Ghan and Schwartz, 2007; Remer et al., 2008; Kulmala et al., 2008). Of these, continuous in situ measurements are currently the only means to get both versatile and accurate aerosol data with sufficient temporal resolution.

Most long-term aerosol measurements have been conducted in cities and rural areas in Europe and North America in locations that are relatively easy to access. The majority of such measurements have been based on the aerosol mass concentration, because this quantity is normally used in air quality standards. Particle number concentration or size distribution measurements are fewer in number. Very few long-term aerosol measurements have been made in South America, Africa or East Asia, and the conducted studies have usually

Published by Copernicus Publications on behalf of the European Geosciences Union. 
focused on large cities in which air quality is the major issue. Any long term measurements in rural or background areas in those regions are rear, even though it is known that some large areas (e.g. India and South-Eastern China) are exposed high level of aerosol pollution (Lelieveld et al., 2001; Nakajima et al., 2007; Ramanathan et al., 2007a). Such high aerosol levels affect both climate and human health in those areas (Pandey et al., 2005; Lau and Kim, 2006; Oanh et al., 2006; Pathirana et al., 2007; Nakajima et al., 2007; Ramanathan et al., 2007b).

Continuous aerosol measurements have mostly been carried out at low altitudes. This is logical, as people tend to live in low altitude areas, and convenient, as stations are easier to be built and operated there. However, low-altitude measurements are easily affected by local aerosol sources and smallscale meteorological patterns. Regional and large-scale concentration levels of aerosol particles can therefore be observed more reliably in measurements conducted at high altitudes.

High-altitude aerosol measurements can be made by using several different approaches. The first one is setting the instruments in aircrafts and then flying a pre-determined route going usually back and fort the same line in different altitudes (e.g. Reus et al., 2000; Keil and Wendisch, 2000). Another technique is to set the instruments in a hot air balloon, and fly it up and down for a few times, or to follow the same air parcel for some time as the balloon flies with the wind (Tobo et al., 2007; Laakso et al., 2007). Low-cost and low-weight aerosol instruments can also be attached to weather balloons to obtain vertical profiles of the aerosol properties in the atmosphere (Hoffmann, 1993). The only high-altitude measurement technique that allows continuous long-term measurements is to use a measurement site that is located high on a mountain, preferably on top, or in a high mountain saddle (Weber et al., 1996; Nyeki et al., 1998a).

The mountain top measurement data around the world have revealed quite variable aerosol concentrations both with the location and season. The boundary-layer air and freetropospheric air can also in some cases be identified and studied separately, in which case we get information on the temporal pattern how these two types of air change around the mountain (Nyeki et al., 1998b; Nishita et al., 2008; Shaw, 2007).

In this work we have measured and analyzed almost two years of continuous aerosol size distribution and number concentration data from a mountain top observatory in central China. The objectives of these measurements have been i) to investigate the general level and seasonal variation of particle size distribution and number concentration in Asian continental background air, ii) to study whether the brown cloud over large areas of China extends as far into inland China as Mount Waliguan, and iii) to find out whether differences in aerosol size distribution in planetary boundary layer air and in free troposphere air can be seen at Mount Waliguan.

\section{Materials and methods}

\subsection{Measurement site}

The Waliguan Baseline Observatory $\left(36^{\circ} 17^{\prime} \mathrm{N}, 100^{\circ} 54^{\prime} \mathrm{E}\right.$, $3816 \mathrm{~m}$ a.s.l.) is one of 24 baseline observatories of World Meteorological Organization (WMO) Global Atmosphere Watch (GAW), situated near the top of Mt. Waliguan at the edge of northeastern part of the Qinghai-Xizang (Tibet) Plateau in a remote region of western China. The station is relatively isolated from major industrial sources and populated centers. The closest major settlement is Qiapuqia (GongHe) with a population of 30000 , located $30 \mathrm{~km}$ to the west. The closest cities with more than 1000000 inhabitants are located north-east and east from the station: Xining at a distance of about $90 \mathrm{~km}$ and Lanzhou at the distance of $260 \mathrm{~km}$. There is a row of mountain peaks with height above $4000 \mathrm{~m}$ between Xining and Mount Waliguan (Fig. 1). The most probable pathway of anthropogenic emissions to arrive to the station is along the Yellow River canyon from the more densely populated river valley areas (such as Lanzhou) east of the station (Zhou et al., 2001).

The mountain is a high ridge in east-west direction and rises about $600 \mathrm{~m}$ from the valley in the north and $1300 \mathrm{~m}$ from the Longyangxia reservoir lake in the south, some $12 \mathrm{~km}$ from the station. The lake is on the upper reaches of the Yellow River. The actual top of the mountain is located some hundred meters east of the station, and a couple of tens of meters higher. The surrounding area maintains its natural environment of sparse vegetation along with arid and semi-arid grassland and some desert regions. The population density within $25 \mathrm{~km}$ from the station is less than 6 people per $\mathrm{km}^{2}$. Yak and sheep grazing is the main activity during summer, with small agricultural regions located in the lower valley area (Zhou et al., 2004).

The annual average temperature is $-0.9^{\circ} \mathrm{C}$ with a relatively strong seasonal variation. The monthly average temperatures vary from $-10^{\circ} \mathrm{C}$ in mid-winter to $10^{\circ} \mathrm{C}$ in summer. The wind direction is mostly from east and north-east in summer and from west in winter (Zhou et al., 2003). The Yearly-average wind speed is $4.6 \mathrm{~m} / \mathrm{s}$. The vertical wind pattern is connected to the horizontal wind because of the local landform, such that eastern winds are associated with the downslope vertical wind and western winds with the upslope vertical wind (Zhou et al., 2001). The annual average precipitation at Mount Waliguan is around $350 \mathrm{~mm}$, with most of it occurring in summer when the monsoon low pressure system is located south-west from Mount Waliguan area and moist air is drown in from the lowland areas of eastern China.

\subsection{Instrumentation}

As a part of the GAW network, the Mount Waliguan station is a platform for many different measurements. These measured quantities include meteorological parameters, 


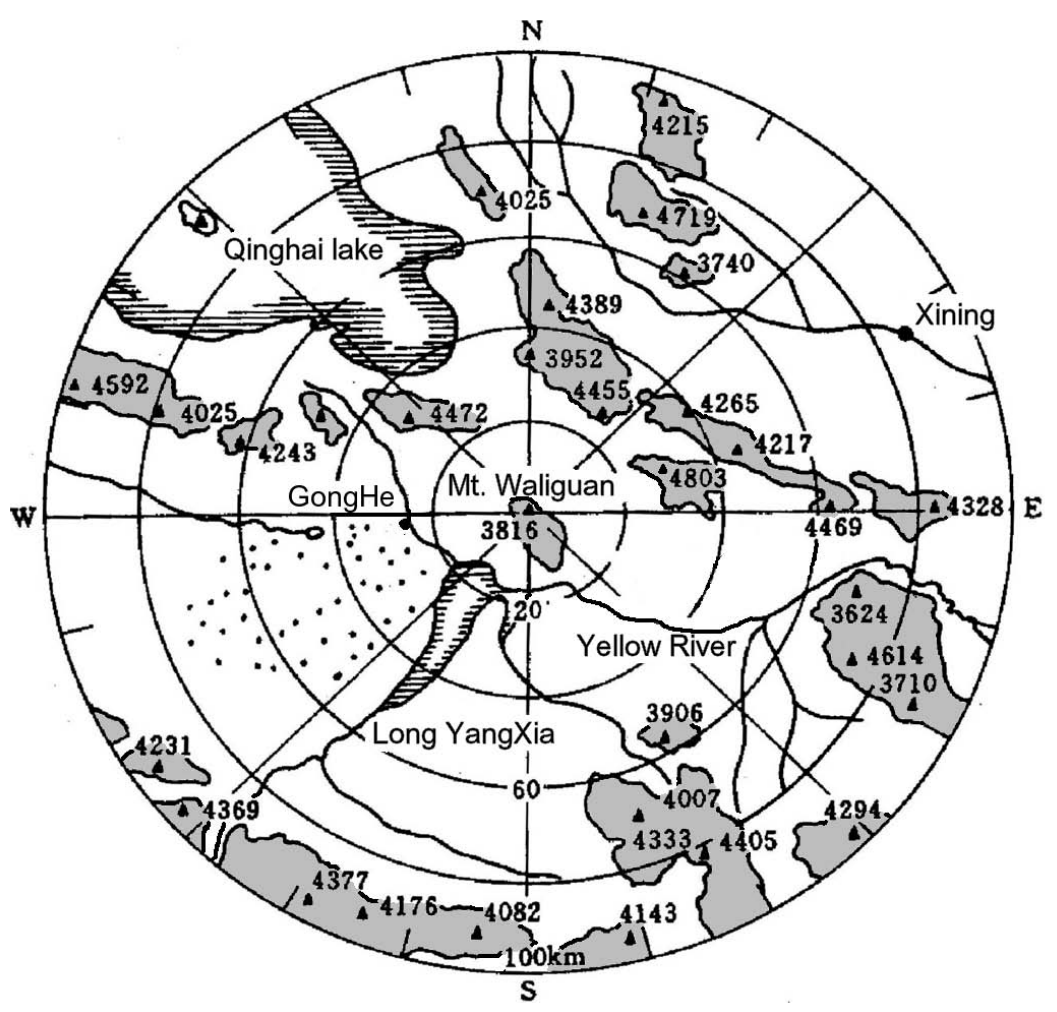

Fig. 1. Map of the area within $100 \mathrm{~km}$ radius from Mount Waliguan. The gray areas have height $3500 \mathrm{~m}$ or more above sea level, and the triangles represent mountain peaks (with height above sea level). The dotted area west from Mount Waliguan is desert.

concentrations of greenhouse gases, reactive gases and surface ozone, precipitation chemistry and some aerosol parameters (http://gaw.empa.ch/gawsis/reports.asp?StationID=12). The aerosol light absorption coefficient has been measured with an aethalometer and aerosol multi-wavelength optical depth with pyrrheliometer since the establishment of the station in 1994. Besides these, the aerosol number size distribution has been measured during 2005-2007 with a differential mobility particle sizer (DMPS) and aerosol number a concentration during 2006 with a condensation particle counter (CPC).

The DMPS system used at Mount Waliguan consists of a 28-cm-long Hauke-type differential mobility analyzer (DMA) with a closed loop sheath flow arrangement, and a condensation particle counter (TSI model 3010) (Komppula et al., 2003). The DMPS measures particles in 30 discrete size classes, one size class at the time. The voltages of the DMA were set so that the geometric means of the size classes range from $10.0 \mathrm{~nm}$ to $500 \mathrm{~nm}$, and are distributed evenly in logarithmic scale. The analysis of the raw data was based on programs and routines developed in the University of Helsinki (Aalto et al., 2001). However, the number concentrations of the two smallest size classes were found unreliable and were therefore removed, leaving the geometric mean diameter of the smallest size class to be $13.1 \mathrm{~nm}$. If the logarithmic widths of the size classes at the end of the scale are assumed to be the same with the other size classes, this leaves us with capability to measure over the mobility diameter range of $12-570 \mathrm{~nm}$. The DMPS system scans the whole measured size range stepwise in approximately five minutes.

The DMPS instrumentation was established at the station on 19 August 2005 and was operational from there on to 9 May 2007. During this period there were two longer gaps when the measurements were not running due to instrumentation failures. These gap periods were from 16 January to 7 April 2006 and from 26 June to 10 September 2006.

The particle number concentration above the $10 \mathrm{~nm}$ diameter was also measured with a butanol based condensation particle counter (TSI model 3010). The upper limit of the CPC measurement size range is determined by the bends of the inlet channel at the station and inside the device. However, since the number concentration of supermicron particles is in almost always negligible compared to that of submicron size fraction, the CPC and DMPS systems should give approximately the same particle number concentration. This allows us to use the CPC data to confirm the DMPS is working correctly and vice versa. The CPC measurements were also suffering from problems at the station, and there are gaps in the CPC data as well. The CPC measurement data from 15 January and ends in 25 November 2006. The longest gap in the data was 18 May-13 August 2006.

FLEXTRA back trajectories (http://tarantula.nilu.no/ trajectories, Stohl et al., 1995) from the site $(625 \mathrm{hPa}$ level, approximately $3950 \mathrm{~m}$ a.s.l.) were calculated for each three 
hours. The trajectories followed the air mass arriving path starting $120 \mathrm{~h}$ before the air mass reached Mount Waliguan. The trajectories consisted of longitude and latitude of the air parcel, as well as altitude from sea level and from the ground.

Meteorological parameters available for this study were the temperature, relative humidity, wind speed and wind direction. All the meteorological parameters were given as five-minute averages.

\subsection{Data processing}

The DMPS data were examined and bad data were removed, including the periods of clear local anthropogenic effects from the station or from the road to the station. These periods were characterized by sharp peaks of Aitken and accumulation mode particle number concentrations in the data. The total particle number concentration from each size distribution in the DMPS measurements was calculated as the sum of all size bins. All the DMPS data and meteorological data were converted into one-hour averages for data handling reasons. If there were less than four data points for any individual hour, the data for that hour was neglected. Also the CPC data was converted into hourly averages.

The hourly-average particle number size distributions were normalized and classified into five groups according to the shape of the normalized size distribution. The normalization was performed in order to better separate by differentlyshaped distributions instead of the different number concentration values. This way the distribution types tell more about the evolution of the particle size distribution. The distribution types were characterized by a dominating nucleation mode (type 1), grown nucleation mode (type 2), dominating Aitken mode (type 3), dominating Aitken and accumulation modes (type 4) and dispersed distribution (type 5). The five distribution types are presented in Fig. 2. The modal parameters of a tri-modal fit for each distribution type are given in Table 1. For each hourly-average size distribution, a number concentration was also calculated separately for nucleation $\left(12 \mathrm{~nm}<\mathrm{d}_{p}<21 \mathrm{~nm}\right)$, Aitken $\left(21 \mathrm{~nm}<\mathrm{d}_{p}<95 \mathrm{~nm}\right)$ and accumulation $\left(95<\mathrm{d}_{p}<570 \mathrm{~nm}\right)$ mode particles.

Trajectories were combined with the data in such a way that each trajectory was attached to the size distribution data at the hour corresponding to the arrival of the air parcel at Mount Waliguan. The same trajectory was also attached to the size distribution data of the previous hour and the following hour. Four sectors were used to separate the trajectories into different groups (Fig. 3). These sectors were $315^{\circ}-45^{\circ}$ (sector 1 , northern grasslands), $45^{\circ}-165^{\circ}$ (sector 2 , densely populated areas of China), $165^{\circ}-270^{\circ}$ (sector 3 , highland areas) and $270^{\circ}-315^{\circ}$ (sector 4 , western deserts). The fraction of the time that each trajectory had spent in each sector was calculated. The same calculation was performed for the air mass height, dividing the air masses into high-altitude air
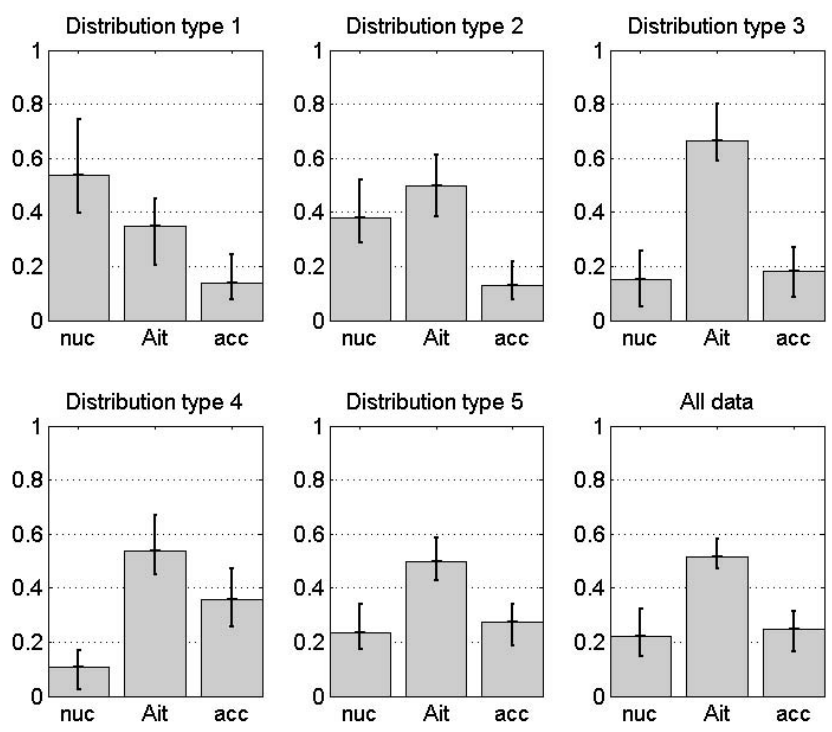

Fig. 2. Median relative concentrations of each mode in the five distribution types and in the total data set. The error bars show the 5 and 95 percentiles.

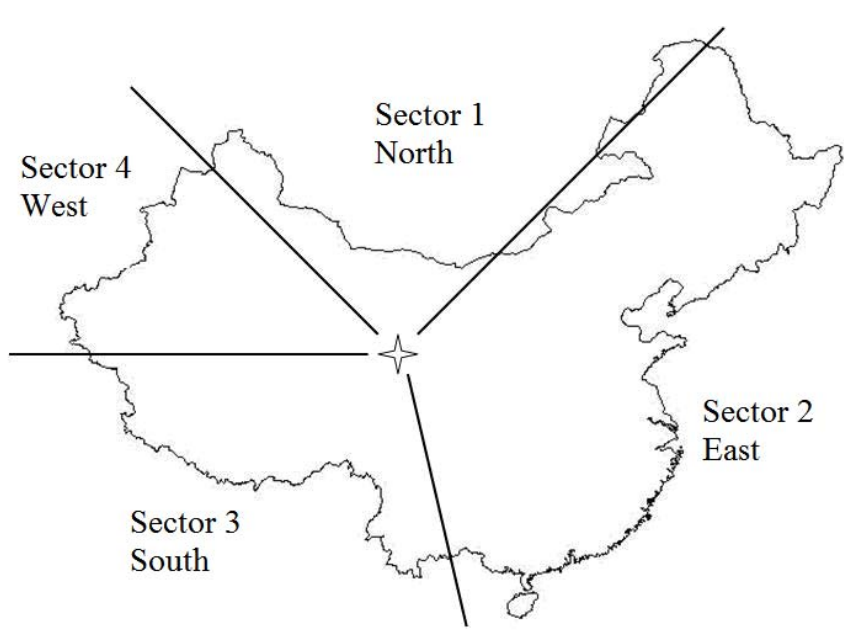

Fig. 3. The location of Mount Waliguan observatory, and the sectors according to which air masses were divided.

$(p<550 \mathrm{hPa})$ and low-altitude air $(p>550 \mathrm{hPa})$. This refers to altitude of approximately $4800 \mathrm{~m}$ a.s.l. (Brasseur et al., 1999). The air mass locations (sector and height) at one day, three days and five days before arrival at Mount Waliguan were also investigated.

The diurnal pattern of aerosol number concentration of each mode was investigated separately for spring (MarchMay), summer (June-August), fall (September-November), and winter (December-February). For all seasons, the seasonal-average number concentration of particles in each mode was calculated for each hour of the day. 
Table 1. The distribution types used in the analysis of the data and the corresponding fitted modal parameters. The $D, \sigma$ and $N$ represent the mean diameter, geometric standard deviation and mean number concentration of each mode, the mode given as subscript. The values are median values with 10 and 90 percentiles in parenthesis. The total number concentration $\left(N_{\text {tot }}\right)$ is obtained from the measured values instead of the fitted ones.

\begin{tabular}{|c|c|c|c|c|c|}
\hline Distribution type & 1 & 2 & 3 & 4 & 5 \\
\hline Number of cases & 770 & 1771 & 1418 & 2262 & 3541 \\
\hline$D_{1}(\mathrm{~nm})$ & $\begin{array}{c}15 \\
(10-28)\end{array}$ & $\begin{array}{c}21 \\
(16-27)\end{array}$ & $\begin{array}{c}26 \\
(19-29)\end{array}$ & $\begin{array}{c}22 \\
(15-28)\end{array}$ & $\begin{array}{c}20 \\
(13-27)\end{array}$ \\
\hline$\sigma_{1}$ & $\begin{array}{c}1.41 \\
(1.26-1.87)\end{array}$ & $\begin{array}{c}1.52 \\
(1.35-1.87)\end{array}$ & $\begin{array}{c}1.49 \\
(1.29-1.85)\end{array}$ & $\begin{array}{c}1.45 \\
(1.27-1.87)\end{array}$ & $\begin{array}{c}1.54 \\
(1.33-1.91)\end{array}$ \\
\hline$N_{1}\left(\mathrm{~cm}^{-3}\right)$ & $\begin{array}{c}2094 \\
(861-6911)\end{array}$ & $\begin{array}{c}1030 \\
(345-3039)\end{array}$ & $\begin{array}{c}143 \\
(0-1102)\end{array}$ & $\begin{array}{c}133 \\
(0-407)\end{array}$ & $\begin{array}{c}410 \\
(150-910)\end{array}$ \\
\hline$D_{2}(\mathrm{~nm})$ & $\begin{array}{c}45 \\
(35-62)\end{array}$ & $\begin{array}{c}47 \\
(33-77)\end{array}$ & $\begin{array}{c}46 \\
(36-56)\end{array}$ & $\begin{array}{c}51 \\
(42-76)\end{array}$ & $\begin{array}{c}48 \\
(39-78)\end{array}$ \\
\hline$\sigma_{2}$ & $\begin{array}{c}1.55 \\
(1.30-2.00)\end{array}$ & $\begin{array}{c}1.64 \\
(1.31-2.00)\end{array}$ & $\begin{array}{c}1.50 \\
(1.32-1.80)\end{array}$ & $\begin{array}{c}1.54 \\
(1.34-1.94)\end{array}$ & $\begin{array}{c}1.53 \\
(1.38-2.00)\end{array}$ \\
\hline$N_{2}\left(\mathrm{~cm}^{-3}\right)$ & $\begin{array}{c}499 \\
(26-1376)\end{array}$ & $\begin{array}{c}516 \\
(47-1680)\end{array}$ & $\begin{array}{c}1274 \\
(302-3512)\end{array}$ & $\begin{array}{c}455 \\
(198-1190)\end{array}$ & $\begin{array}{c}330 \\
(155-747)\end{array}$ \\
\hline$D_{3}(\mathrm{~nm})$ & $\begin{array}{c}125 \\
(90-163)\end{array}$ & $\begin{array}{c}125 \\
(90-170)\end{array}$ & $\begin{array}{c}130 \\
(91-175)\end{array}$ & $\begin{array}{c}147 \\
(117-190)\end{array}$ & $\begin{array}{c}143 \\
(122-163)\end{array}$ \\
\hline$\sigma_{3}$ & $\begin{array}{c}1.72 \\
(1.48-1.99)\end{array}$ & $\begin{array}{c}1.71 \\
(1.43-2.00)\end{array}$ & $\begin{array}{c}1.71 \\
(1.44-2.00)\end{array}$ & $\begin{array}{c}1.71 \\
(1.50-1.98)\end{array}$ & $\begin{array}{c}1.68 \\
(1.50-1.87)\end{array}$ \\
\hline$N_{3}\left(\mathrm{~cm}^{-3}\right)$ & $\begin{array}{c}495 \\
(143-1443)\end{array}$ & $\begin{array}{c}358 \\
(82-946)\end{array}$ & $\begin{array}{c}642 \\
(155-1782)\end{array}$ & $\begin{array}{c}682 \\
(295-1477)\end{array}$ & $\begin{array}{c}441 \\
(196-776)\end{array}$ \\
\hline$N_{\mathrm{tot}}\left(\mathrm{cm}^{-3}\right)$ & $\begin{array}{c}2307 \\
(1329-7239)\end{array}$ & $\begin{array}{c}1843 \\
(874-4858)\end{array}$ & $\begin{array}{c}2446 \\
(690-5523)\end{array}$ & $\begin{array}{c}1334 \\
(743-2597)\end{array}$ & $\begin{array}{c}1102 \\
(835-1968)\end{array}$ \\
\hline
\end{tabular}

Table 2. The sectors in the trajectory analysis (air mass location $24 \mathrm{~h}$ before arriving to the site) and aerosol size distribution parameters attached to them. The percentages in the Distribution rows are the number of the cases with that type of distribution divided by the number of all cases with the arriving sector determined by the column. The concentrations are in ambient pressure.

\begin{tabular}{lccccc}
\hline Parameter & $\begin{array}{c}\text { Sector 1 } \\
\text { North }\end{array}$ & $\begin{array}{c}\text { Sector 2 } \\
\text { East }\end{array}$ & $\begin{array}{c}\text { Sector 3 } \\
\text { South }\end{array}$ & $\begin{array}{c}\text { Sector 4 } \\
\text { West }\end{array}$ & All data \\
Compass angle $\left(^{\circ}\right)$ & $315-45$ & $45-165$ & $165-270$ & $270-315$ & $0-360$ \\
\hline Number of cases & 904 & 1586 & 1300 & 4928 & 8678 \\
Distribution 1 & $7.9 \%$ & $4.0 \%$ & $8.0 \%$ & $8.9 \%$ & $7.8 \%$ \\
Distribution 2 & $13.1 \%$ & $8.6 \%$ & $23.9 \%$ & $23.1 \%$ & $19.6 \%$ \\
Distribution 3 & $26.5 \%$ & $27.6 \%$ & $16.4 \%$ & $6.9 \%$ & $14.2 \%$ \\
Distribution 4 & $26.5 \%$ & $46.2 \%$ & $18.9 \%$ & $15.6 \%$ & $22.9 \%$ \\
Distribution 5 & $26.0 \%$ & $13.7 \%$ & $32.8 \%$ & $45.4 \%$ & $35.9 \%$ \\
Mean $N_{\text {nuc }}\left(\mathrm{cm}^{-3}\right)$ & 581 & 577 & 692 & 555 & 570 \\
Mean $N_{\text {Ait }}\left(\mathrm{cm}^{-3}\right)$ & 1149 & 1488 & 1238 & 868 & 1060 \\
Mean $N_{\text {acc }}\left(\mathrm{cm}^{-3}\right)$ & 425 & 606 & 467 & 362 & 430 \\
Mean $N_{\text {tot }}\left(\mathrm{cm}^{-3}\right)$ & 2120 & 2637 & 2356 & 1753 & 2040 \\
Median $N_{\text {nuc }}\left(\mathrm{cm}^{-3}\right)$ & 277 & 222 & 368 & 304 & 290 \\
Median $N_{\text {Ait }}\left(\mathrm{cm}^{-3}\right)$ & 826 & 1070 & 763 & 598 & 690 \\
Median $N_{\text {acc }}\left(\mathrm{cm}^{-3}\right)$ & 379 & 559 & 319 & 306 & 330 \\
Median $N_{\text {tot }}\left(\mathrm{cm}^{-3}\right)$ & 1533 & 1941 & 1511 & 1229 & 1390 \\
Mean $N_{\text {Ait }} / N_{\text {acc }}$ & 3.18 & 2.76 & 2.90 & 2.58 & 2.65 \\
\hline
\end{tabular}




\section{Results}

\subsection{General}

In hourly-average data, the ratio in the total particle number concentrations between the CPC and DMPS $\left(N_{\mathrm{CPC}} / N_{\mathrm{DMPS}}\right)$ was, on average, 1.08 with a standard deviation of 0.39 . The 25 and 75 percentiles were 0.85 and 1.18 , respectively, and the 10 and 90 percentiles 0.79 and 1.49 , respectively (Fig. 4). However, the ratio occasionally reached values up to 5. These extreme cases were typically observed when a large fraction of the particles measured by the DMPS were in the nucleation mode $\left(d_{p}<21 \mathrm{~nm}\right)$. This indicates that the counting efficiency of the measurement devices is different for particles with a small diameter. To estimate the effect of the nucleation mode on $N_{\mathrm{CPC}} / N_{\mathrm{DMPS}}$, the data with nucleation mode particle number concentration to total particle number concentration ratio $\left(N_{\text {nuc }} / N_{\text {tot }}\right)$ of 0.392 (average + 1 standard deviation $N_{\text {nuc }} / N_{\text {tot }}$ ) or more were excluded and $N_{\text {CPC }} / N_{\text {DMPS }}$ were counted anew. In this case the average ( \pm standard deviation) $N_{\text {CPC }} / N_{\text {DMPS }}$ was $1.01( \pm 0.29)$, the 25 and 75 percentiles were 0.84 and 1.08 , respectively, and the 10 and 90 percentiles were 0.79 and 1.34 , respectively. The new histogram is also presented in Fig. 4. The agreement between the CPC and DMPS values gives us confidence that the DMPS values can be trusted. The results presented later in this paper are based on the data measured with the DMPS, and with the high $N_{\text {nuc }}$ values included, unless otherwise mentioned. The concentrations reported here are given at ambient pressure, unless otherwise mentioned.

The average (with 10-90 percentiles) number concentration of all $(12-570 \mathrm{~nm})$ particles during the whole measurement period was $2030(820-3820) \mathrm{cm}^{-3}$ at the ambient pressure. The average concentrations of particles in each mode were $570(110-1680) \mathrm{cm}^{-3}$ for the nucleation mode $(12 \mathrm{~nm}$ $\left.<d_{p}<21 \mathrm{~nm}\right), 1060(420-2150) \mathrm{cm}^{-3}$ for the Aitken mode $\left(21 \mathrm{~nm}<d_{p}<95 \mathrm{~nm}\right)$ and $430(160-780) \mathrm{cm}^{-3}$ for the accumulation mode $\left(95 \mathrm{~nm}<d_{p}<570 \mathrm{~nm}\right)$. The corresponding median values were $1390 \mathrm{~cm}^{-3}, 290 \mathrm{~cm}^{-3}, 690 \mathrm{~cm}^{-3}$ and $330 \mathrm{~cm}^{-3}$. The average Aitken to accumulation mode particle number concentration ratio was 2.65 .

The normalized size distributions were classified into five categories, as explained in the data processing section (Fig. 2). The categories follow the growth of new particles from recent nucleation (distribution type 1 ) to a grown nucleation mode (type 2) and to Aitken mode (type 3 ). The type 4 distribution can also be reached as the particles grow in size, but it might contain a significant portion of primary particles as well. The type 5 distribution is flatter than the other ones, and also in most occasions lower in the total number concentration. Such a distribution can be reached by aging the air mass and mixing different types of air. It can also be seen as a typical background distribution before a new particle formation or primary particle emission happens.

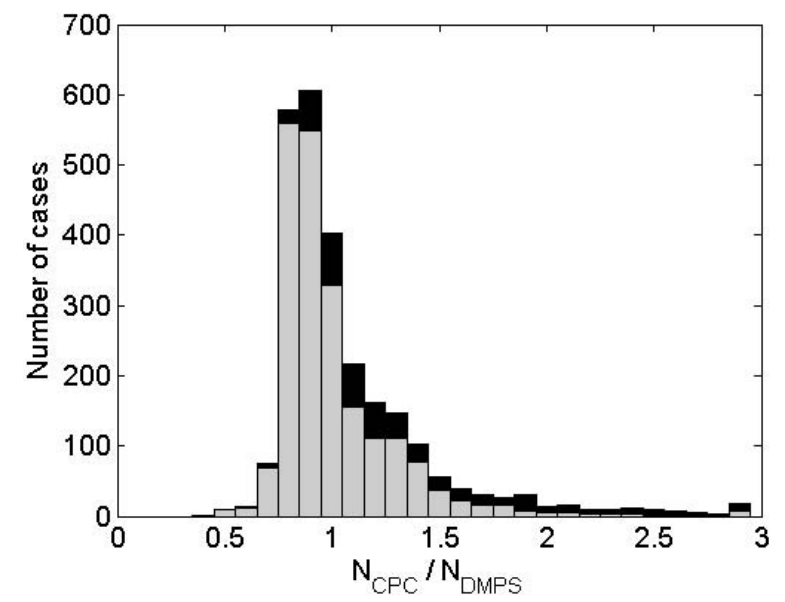

Fig. 4. A histogram showing the ratio of particle number concentration obtained from CPC to that obtained from the DMPS. The gray and black bars together show the total data and the gray bars only the data where periods with dominant nucleation mode $\left(N_{\text {nuc }} / N_{\text {tot }} \geq 0.392\right)$ are removed.

\subsection{Comparison to other measurements}

There are not many long-term aerosol measurements conducted in rural areas in East Asia, nor are there many measurements at such high altitudes either. The best measurements to compare our results with are those conducted at similar altitude (3454 m) at Jungfraujoch in the Swiss alps (Weingartner et al., 1999; Nyeki et al., 1998b), those by Nishita et al. (2007) at Mount Norikura (2770 m) in Japan, those by Shaw (2007) at the top of Mount Lemnon (2790 m) in Arizona, USA and several measurements at the Himalayan region in India and Nepal. Also Measurements in southern Siberia (Koutsenogi and Jaenicke, 1994; Heintzenberger et al., 2008; Paris et al., 2009) can be used for comparison to link the Mount Waliguan measurements to the regional context.

When comparing the particle number concentrations measured at different altitudes, the measured values need to be calculated to the same pressure level to be comparable. In this study we have used the sea level pressure $1013 \mathrm{hPa}$. At this pressure the average (with 10 and 90 percentiles) particle number concentration at Mount Waliguan are 3290 (1330$6190) \mathrm{cm}^{-3}$ for the total particle number concentration, 920 $(170-1890) \mathrm{cm}^{-3}$ for the nucleation mode, $1720(680-3480)$ $\mathrm{cm}^{-3}$ for the Aitken mode and $700(260-1260) \mathrm{cm}^{-3}$ for the accumulation mode. All of the values of the other measurements presented here have been either reported at the sea-level pressure, or have been converted into that pressure based on reported average pressures at the measurement site, or based on the measurement site height, using a formula presented in Brasseur et al. (1999).

The general level of submicron aerosol number concentration at Mount Waliguan was significantly higher that that measured at Jungfraujoch. At Jungfraujoch the annual 
average number concentration of particles $(10-750 \mathrm{~nm})$ was $900 \mathrm{~cm}^{-3}$ (Weingartner et al., 1999), calculated by averaging the data over a period of one month and then fitting two lognormal modes to the averaged size distribution. At Mount Norikura the measurements covered the particle size range below 9-300 nm, and the measurements were conducted in late summer and early fall. The reported median number concentrations in that size range at Mount Norikura were 300$1300 \mathrm{~cm}^{-3}$, depending on the type of air mass (Nishita et al., 2007). These values are closer to those measured by us, but still smaller. Shaw (2007) measured mean particle number concentration of $2000 \mathrm{~cm}^{-3}$ in the size range $(12-390 \mathrm{~nm})$ during late winter and spring (February-May) at night time, when the conditions are expected to represent the free troposphere. The data processing method used by Shaw (2007) was the same as used by Weingartner at Jungfaujoch (Weingartner et al., 1999). The daytime particle number concentrations (that represent the planetary boundary layer conditions) measured by Shaw (2007) were clearly higher than the night-time values, being more similar to the mean and median values found in this study.

Our measurements are best comparable those conducted by Komppula et al. (2009) in Mukteshwar at the height of $2180 \mathrm{~m}$ a.s.l. in the foothills of the Indian Himalayas. These measurements were carried out at the same time, and with a very similar instrumentation, as the measurements at Mount Waliguan. Komppula et al. (2009) reported an average particle $(10-800 \mathrm{~nm})$ number concentration of $3420 \mathrm{~cm}^{-3}$. Gajaranda et al. (2005) measured particle concentrations during years 1996-2003 at three measuring sites at different altitudes (1150-2530 m a.s.1.) in the Indian Himalayas. They reported average particle concentrations $(1-1000 \mathrm{~nm})$ between 980 and $3450 \mathrm{~cm}^{-3}$, being highest at the site located at lowest altitude and lowest at the one located at highest altitude. The higher the altitude was, the lower was the average particle number concentration. Bonasoni et al. (2008) reported an average value of $880 \mathrm{~cm}^{-3}$ for the particle $(10-500 \mathrm{~nm})$ number concentration measured at the Nepalese ABC-Pyramid observatory in the Khumbu valley in Nepalese Himalayas at the height of $5079 \mathrm{~m}$ a.s.l.

The climate at Mount Waliguan differs significantly from that in India and Nepal. The annual pattern is affected by the monsoon, but there is no season characterized by high precipitation at Mount Waliguan, even though most precipitation occurs during summer. The climate is more similar to that of southern Siberia. Therefore the comparison should be extended to measurements in remote location in that region, even though the Siberian sites are located on significantly lower altitude. Koutsenogii and Jaenicke (1994) measured particle concentrations with a diffusion battery on a hill top (1000 m a.s.l.) west of Lake Baikal. Their measurements lasted only for two weeks in the middle of summer. They report a mean particle number concentration of $5700 \mathrm{~cm}^{-3}$ during their measurements, and a particle size distribution which is dominated by nucleation and Aitken mode particles. Dal Maso et al. (2008a) reported average particle number concentration $(3-50 \mathrm{~nm})$ of $4690 \mathrm{~cm}^{-3}$ at the same site for continuous one-year measurement period (March 2005-March 2006). Heintzenberg et al. (2008) measured particles in central Siberia, almost $3000 \mathrm{~km}$ from Mount Waliguan, with a 300-m-high tower in late fall 2006 and entire spring 2007. They reported particle number concentrations of $400-4000 \mathrm{~cm}^{-3}$ (5\% and $95 \%$ values) with a median of $1200 \mathrm{~cm}^{-3}$. Paris et al. (2009) measured particle s over southern Siberia with an aircraft flying at the altitude of $0-7 \mathrm{~km}$. They measured only four days in April and four days in September. They reported median values of $190 \mathrm{~cm}^{-3}$ in April and $215 \mathrm{~cm}^{-3}$ in September in altitude below $3 \mathrm{~km}$. The corresponding $10 \%$ and $90 \%$ values were $90-580 \mathrm{~cm}^{-3}$ in April and $75-1500 \mathrm{~cm}^{-3}$ in September. The particle number concentrations measured at Mount Waliguan were higher that those measured at the Siberian sites, except for the summer measurements at Lake Baikal.

The total particle number concentration can be affected by primary particle emissions and by the formation of new particles from gaseous precursors. A more relevant quantity for estimating the effect of anthropogenic activity is the number concentration of accumulation mode particles $\left(N_{\mathrm{acc}}\right)$. The reported diameter limits between Aitken and accumulation mode particles are usually $90-100 \mathrm{~nm}$, varying from one publication to another. Concerning high-altitude sites, Shaw (2007) reported $N_{\text {acc }}$ of $260 \mathrm{~cm}^{-3}$ at Mount Lemnon (in free troposphere conditions) and Weingartner et al. (1999) a value of $220 \mathrm{~cm}^{-3}$ at Jungfaujoch (average over all cases). At Mount Norikura Nishita et al. (2007) measured values of $N_{\text {acc }}$ around $100 \mathrm{~cm}^{-3}$ when the air mass had been affected by recent precipitation, and $350-400 \mathrm{~cm}^{-3}$ when no precipitation had altered the air mass during the previous days. For the lower altitude stations the average $N_{\text {acc }}$ values vary from $230 \mathrm{~cm}^{-3}$ (background) to $580 \mathrm{~cm}^{-3}$ (rural) to $1650 \mathrm{~cm}^{-3}$ (urban) in Finland (Laakso et al., 2003; Dal Maso et al., 2008b). Similar background values of $N_{\text {acc }}$ were found in Siberia (Koutsenogii et Jaenicke, 1994; Heintzenberger et al., 2008). In some megacities average values as up to $10000 \mathrm{~cm}^{-3}$ (Beijing) (Wehner et al., 2008) and $25000 \mathrm{~cm}^{-3}$ (New Delhi) (Mönkkönen et al., 2005) have been reported for $N_{\mathrm{acc}}$. In Mount Waliguan, the value of $N_{\mathrm{acc}}$ (calculated to sea level pressure) averaged $700 \mathrm{~cm}^{-3}$ and varied with the air mass direction. The lowest average values of $N_{\text {acc }}$ were $586 \mathrm{~cm}^{-3}$ in western air masses and highest $982 \mathrm{~cm}^{-3}$ in eastern air masses. These values would be expectable for a rural site at low altitudes, but are higher than the values measured at other high-altitude sites. This was the case especially in the air masses coming from east to Mount Waliguan.

\subsection{Temporal variation}

Although there were major breaks in the particle number concentration measurements, some seasonal variation could be observed from the combined DMPS and CPC data 
(Fig. 5). The particle number concentration seemed to be higher during the summer months and lower during the rest of the year. There was also a long period with high particle number concentrations in December 2005 and January 2006, but no similar pattern was found in the following winter. The daily-average particle number concentration (measured with DMPS) varied (1\% and 99\% percentiles) from 370 to $7600 \mathrm{~cm}^{-3}$, while the hourly averages varied from 230 to $10390 \mathrm{~cm}^{-3}$. The monthly-median particle number concentrations derived from the combined DMPS and CPC data varied from $1130 \mathrm{~cm}^{-3}$ (March) to $1920 \mathrm{~cm}^{-3}$ (June), the corresponding mean values being equal to 1520 and $2540 \mathrm{~cm}^{-3}$, respectively. The period with high particle number concentration during the winter 2005-2006 lifted the December and January average and median particle concentrations close to those measured in June. The same analysis was made to the nighttime (00:00-08:00) data to avoid the effects of possible diurnal variation. The seasonal pattern did not change significantly, but the $99 \%$ value of hourly number concentrations decreased to $7590 \mathrm{~cm}^{-3}$. There was no aerosol data for the month of July and also less data for June and August than for other months because of the measurement period and gaps in the measurements.

Several studies conducted at mountain sites have shown a diurnal pattern of changes between air coming from the planetary boundary layer (PBL) during the day and from the free troposphere (FT) during the night (Nyeki et al., 1998b; Shaw, 2007; Nishita et al., 2008). A diurnal pattern in the vertical wind speed at Mount Waliguan has also been reported (Wang et al., 2006). The division of observations into PBL and FT categories can be done in several different ways. Shaw (2007) compared the difference in the potential temperature between mountain observations and observations conducted at the mountain base. Nyeki et al. (1998b) and Nishita et al. (2008) used synoptic or local meteorological conditions as criteria for selection. Besides these methods, also water vapor pressure and concentrations of some relatively long-lived trace gases produced in PBL, such as CO, could be useful criteria when looking at the type of air.

No trace gas data were available for this study, even though some trace gases are measured at the site. Neither are there other measurement sites at the mountain base, from which one could obtain the temperature for calculating the potential temperature difference. The daily pattern in the horizontal wind direction at Mount Waliguan was not clear, unlike the one reported by Wang et al. (2006), and could not be used to estimate the vertical wind pattern. The water vapor pressure was investigated as a potential criterion for pattern in changes between PBL and FT air. Water is expected to enter the air mostly by evaporation from the surface, especially since there is a large lake in the vicinity of the measurement station. Water vapor was calculated from $\mathrm{RH}$ and $T$ according to Buck (1981). Rapid changes in the water vapor pressure were compared to rapid changes in the aerosol size distribution. Although there were sudden changes in both of

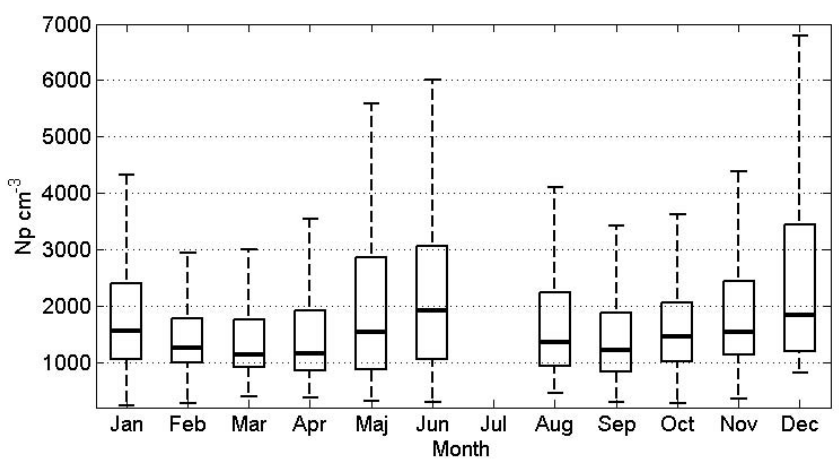

Fig. 5. The seasonal variation of particle number concentration at Mount Waliguan. The median values (red lines inside the boxes), 25 and 75 percentile values (box upper and lower limits) and 5 and 95 percentile values (error bars) of $N_{p}$ for each month in the combined DMPS and CPC data. There were no data available for the month of July.

these quantities, they were found not to coincide with each other. The typical diurnal pattern of the water vapor pressure was actually quite opposite to that expected: when the temperature rose during the day, there was typically a decrease in the water vapor pressure. This indicates that there is no clear pattern between PBL and FT air, but the mixing was rather taking place within the planetary boundary layer.

There was, however, a diurnal pattern in the number concentration of nucleation mode particles (Fig. 6). This was true for all seasons. The nucleation mode particle number concentration increased between the noon and around 17:00 Beijing time and gradually decreased during the rest of the day. The Beijing time is used here because it is the official time of China. The local solar time is $1 \mathrm{~h}$ and $20 \mathrm{~min}$ behind Beijing time. A similar pattern was also seen for the Aitken mode in the summer data. Such patterns were not found for the accumulation mode or for the Aitken mode during other seasons. One should keep in mind that the amount of summer data was significantly lower than those in other seasons. When the periods of dominant nucleation mode $\left(N_{\text {nuc }} / N_{\text {tot }} \geq\right.$ 0.392) were removed, the nucleation mode pattern disappeared, and the summer Aitken mode pattern shifted towards evening.

Average and median particle number concentration of each mode for afternoon daytime (14:00-18:00 Beijing time) values and nighttime (02:00-06:00 Beijing time) values were calculated for each season. The ratios between the daytime and nighttime values were also calculated in order to obtain the differences in the air masses (Table 3). For the nucleation mode this ratio was high throughout the year when average values were used (1.75 in winter and 2.25-2.58 during other seasons). A similar behavior was not found for median values the ratio varying from 0.89 (summer) to 1.25 (fall). These values indicate that the high average values originated from a few periods of very high nucleation mode particle number 

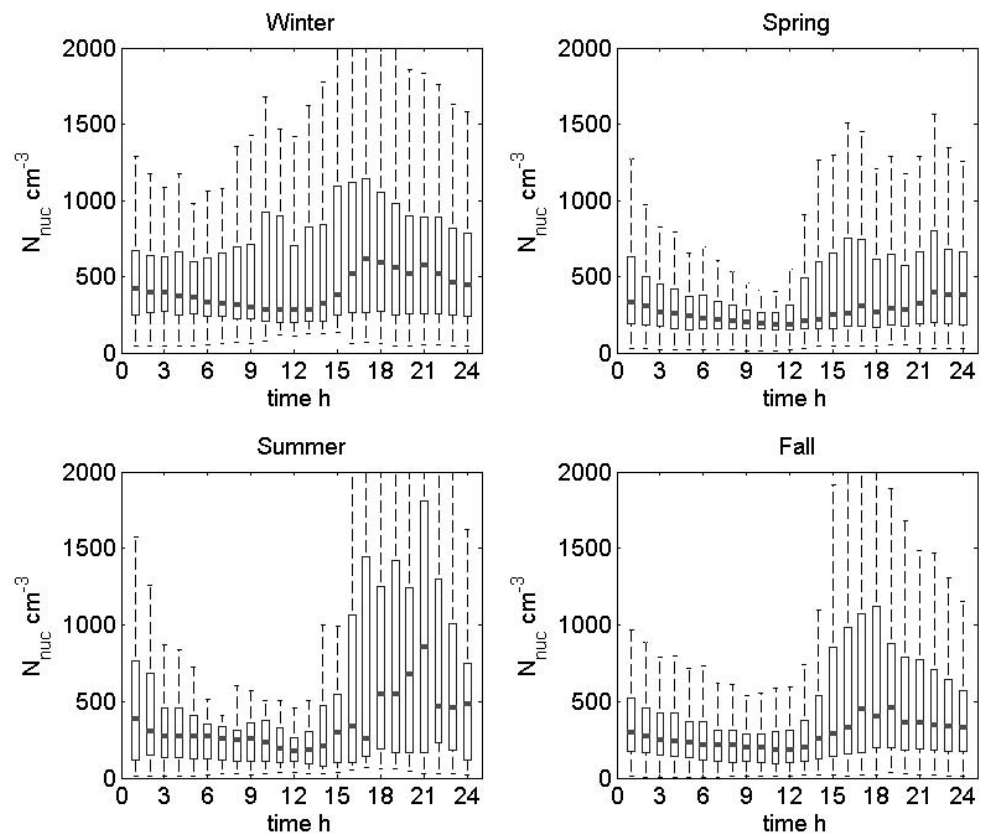

Fig. 6. The average diurnal pattern of nucleation mode particle number concentration variation in different seasons. The solar noon time at the site is 13:20. The number concentration axis is logarithmic. The line in the middle of each box is the median value, the box extends from $25 \%$ to $75 \%$ values, and the error bars are the $5 \%$ and $95 \%$ limits.

concentrations. Aitken mode particle number concentrations were typically a bit higher during nighttime than daytime, especially during summer, when the ratios of both average and median values were below 0.7 . The accumulation mode particle number concentration during daytime was within $\pm 10 \%$ of that during the nighttime almost throughout the year. Such mid-day maximum of accumulation mode particles as observed by Komppula et al. (2008) and Gajaranda et al. (2005) was not seen at Mount Waliguan. These findings indicate that there is no systematic pattern of changes between PBL air and FT air at the site, and that the increase in nucleation mode particle concentrations is caused by some other phenomenon.

Atmospheric new particle formation events have been observed all around the world (Kulmala et al., 2004, Kulmala and Kerminen, 2008), including a high-altitude site in Nepal (Venzac et al., 2008). Such events were also observed at Mount Waliguan, mostly during other seasons than winter. A detailed analysis of those events is beyond the scope of this study. New particle formation events are a strong candidate for the observed increase in nucleation mode particle number concentrations at Mount Waliguan. The increase at Mount Waliguan took place later than what is usually observed elsewhere (Kulmala et al., 2004). The delay can be explained by the difference in the Beijing time (used in this study) and local solar time. Another factor explaining the delay is the minimum diameter of measured particles, which was quite high in our case. The growth of newly-formed particles into sizes detectable with our instruments takes at leas a couple of hours or even more. The influence of new particle formation
Table 3. The ratios of daytime (14:00-18:00) to nighttime (hours 02:00-06:00) average and median number concentrations of particles of each mode during each season.

\begin{tabular}{lcccc}
\hline \multicolumn{5}{c}{ Daytime average/Nighttime average } \\
Season & Nucleation & Aitken & Accumulation & Total \\
\hline winter & 1.75 & 1.04 & 1.02 & $\mathbf{1 . 1 9}$ \\
spring & 2.47 & 0.86 & 0.97 & $\mathbf{1 . 1 8}$ \\
summer & 2.25 & 0.67 & 1.04 & $\mathbf{0 . 9 6}$ \\
fall & 2.58 & 0.97 & 1.09 & $\mathbf{1 . 3 1}$ \\
total & $\mathbf{2 . 2 0}$ & $\mathbf{0 . 9 3}$ & $\mathbf{1 . 0 3}$ & $\mathbf{1 . 2 0}$ \\
& \multicolumn{5}{c}{} \\
Daytime median/Nighttime median & \\
winter & 1.19 & 0.95 & 1.09 & $\mathbf{0 . 9 9}$ \\
spring & 0.90 & 0.88 & 0.97 & $\mathbf{0 . 9 1}$ \\
summer & 0.89 & 0.63 & 1.08 & $\mathbf{0 . 8 0}$ \\
fall & 1.25 & 1.03 & 1.11 & $\mathbf{1 . 1 5}$ \\
total & $\mathbf{1 . 0 8}$ & $\mathbf{0 . 9 7}$ & $\mathbf{1 . 0 6}$ & $\mathbf{1 . 0 5}$ \\
\hline
\end{tabular}

events on the number concentration of Aitken mode particles was clearly visible in the summer data (Fig. 7). The increase in the Aitken mode particle number concentration took place a few hours later than in nucleation mode, as it takes time for the particles to grow into Aitken mode size. The amount of summer data was less that that in other seasons. During the other seasons the new particles did not grow enough as a single mode, or the new particle formation events did not occur frequently enough, to be seen in the seasonally averaged 
diurnal pattern of the Aitken mode particle number concentration. After growing into Aitken and possibly accumulation mode, the nucleated particles contribute to the seasonal number concentration pattern in those modes as well.

\section{Trajectory analysis}

The trajectory analysis of the data revealed that in almost two thirds of the cases, the air mass had spent more than $50 \%$ of the trajectory time in the western sector, even though it was the narrowest of all the sectors. In the remaining one third of the cases, the air masses were distributed roughly equally between the three other sectors. In only $7 \%$ of the cases did the air mass spend not more than half of the five day time in any of the sectors. When the same analysis was made according to the air mass location $24 \mathrm{~h}$ before arriving to the station, the dominance of the western sector was not that high, yet still more than $50 \%$ of the cases.

When the location of air mass $24 \mathrm{~h}$ before arriving at the station was used as the classification criteria, particle number concentrations in air masses coming from the more densely populated eastern sector were higher than in other air masses (Table 2). Eastern air masses were also typically associated with particle number-size distributions of types 3 and 4 (see data processing). Distribution types 1 and 2 were significantly less abundant in the eastern air masses than in the other ones, indicating low frequency of new particle formation events. Air masses coming from south and west were more often associated with distribution types 2 and 5 (Fig. 8). Western air masses were associated with the lowest mean number concentration of particles (Table 2). As the usual air mass moving direction in the area during the measurement period was from west to east, the air masses arriving at the site from east often originated from other sectors (mostly the western sector) and spent only the last day or two in the eastern sector (Table 4). It also means that the eastern air masses were more probably affected by regional pollution sources (i.e. Xining, Lanzhou), rather than sources in the denselypopulated coastal regions in China. Distribution types 2 and 5 were associated more commonly with air coming from high altitude, based on the trajectory analysis, whereas distribution type 4 was clearly connected to low altitude air.

One method to estimate the age of the particles in an air mass is the Aitken to accumulation mode particle number concentration ratio. (Komppula et al., 2009) This ratio is typically above unity when the particles are produced within the last couple of days. In more aged air masses this ratio is usually is around or below unity, as both particle growth and removal processes shape the distribution towards a dominating accumulation mode. The average Aitken to accumulation mode particle number concentration ratio at Mount Waliguan varied from 2.6 to 3.2 depending on the air masses. The highest values were obtained in air masses coming from west, and lowest values in eastern air masses. These values are very different from the results of Komppula et al. (2009) at
Table 4. The location (sector) of air mass 5 days before arrival to Mount Waliguan as function of the location 1 day before arrival.

\begin{tabular}{llcccc}
\hline $\begin{array}{l}\text { Air mass location } 1 \text { day } \\
\text { before arrival to } \\
\text { Mount Waliguan }\end{array}$ & Air mass location 5 days before arrival to Mount Waliguan \\
Sector & $\begin{array}{l}\text { Number of } \\
\text { cases }\end{array}$ & Sector 1 & Sector 2 & Sector 3 & Sector 4 \\
\hline 1 & 904 & $38 \%$ & $7 \%$ & $3 \%$ & $52 \%$ \\
2 & 1586 & $27 \%$ & $27 \%$ & $6 \%$ & $40 \%$ \\
3 & 1312 & $9 \%$ & $2 \%$ & $22 \%$ & $68 \%$ \\
4 & 4949 & $17 \%$ & $1 \%$ & $6 \%$ & $76 \%$ \\
\hline
\end{tabular}

Indian Himalayas, where the ratio was about unity. The ratios observed at Mount Waliguan are more similar to those observed at sites where the particle number concentration is lower and the particle size distribution is dominated by recently formed particles. This indicates that the observed particles were produced within a few hundred kilometers from Mount Waliguan instead of being transported from more distant source regions.

When a running 24-h average was used, both Aitken and accumulation mode number concentrations correlated weakly $\left(R^{2} \approx 0.2-0.3\right)$ with the time fraction the air mass had spent in the eastern sector, and anticorrelated with similar strength with the time fraction in western sector. The nucleation mode fraction $\left(N_{\text {nuc }} / N_{\text {tot }}\right)$ behaved in the opposite way. The correlations were a bit stronger when the numbersize distributions were normalized. Other correlations between the modal number concentrations and air masses were not significant. The observed correlations support the interpretation that new particles are produced preferably in air masses arriving from the western sector. There is also some support for the long range transport of anthropogenic pollution from the east, but since the typical Aitken mode concentration is also high in eastern air masses, the air is more probably affected not by the atmospheric brown cloud over Southern and Eastern China (Ramanathan et al., 2007a) but by regional sources within a few hundred $\mathrm{km}$ from the station. As the typical air mass arriving direction is from east during summer and from west during winter, the higher particle number concentrations in eastern air masses contribute to the seasonal particle concentration pattern, especially in the form of accumulation mode particles.

\section{Summary and conclusions}

Aerosol number-size distributions were measured continuously with a DMPS at Mount Waliguan observatory, inland China, at the height of $3816 \mathrm{~m}$ a.s.l. The measured size range was $12-570 \mathrm{~nm}$ in particle mobility diameter. The measurements started in August 2005 and ended in May 2007. There were two major gaps in the time series, each being $2.5-3$ months in length. The data was 

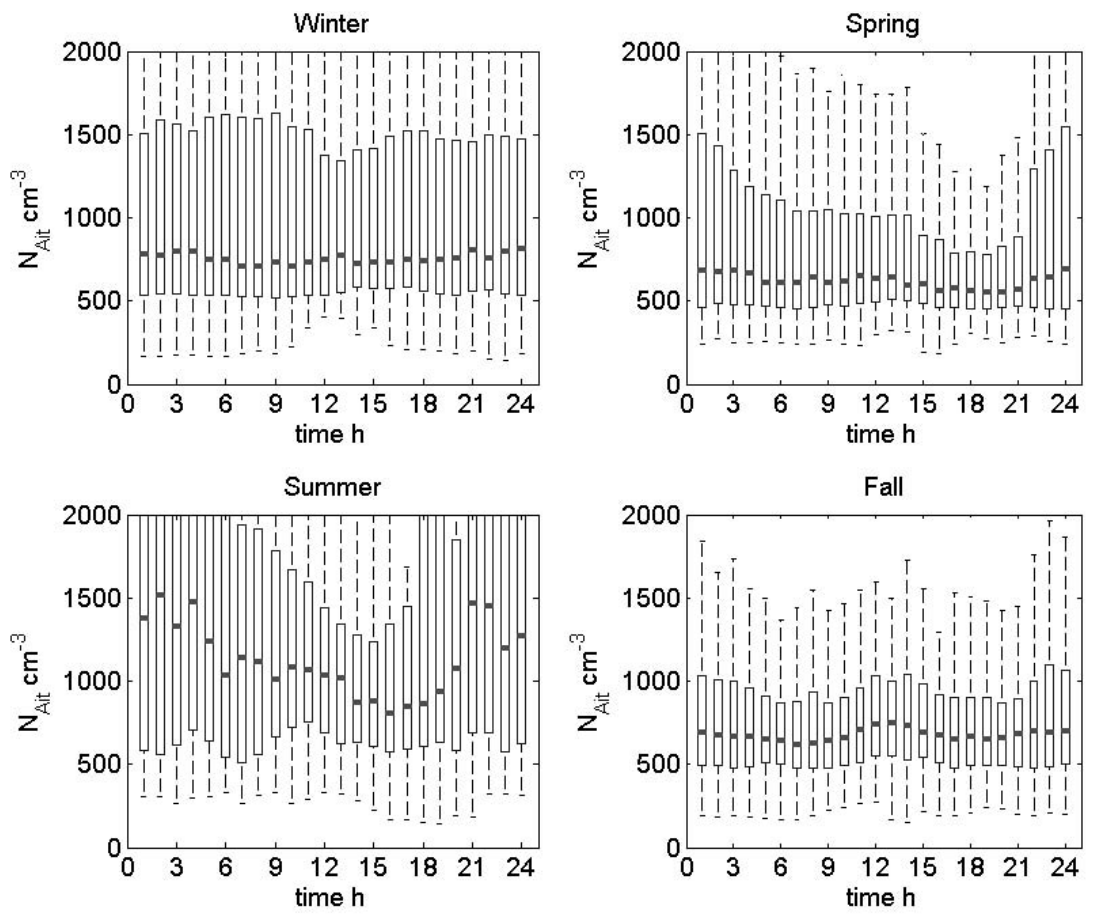

Fig. 7. The average diurnal pattern of Aitken mode particle number concentration variation in different seasons. The solar noon time at the site is 13:20. The number concentration axis is logarithmic. The thicker line in the middle of each box is the median value, the box extends from $25 \%$ to $75 \%$ values, and the error bars are the $5 \%$ and $95 \%$ limits.
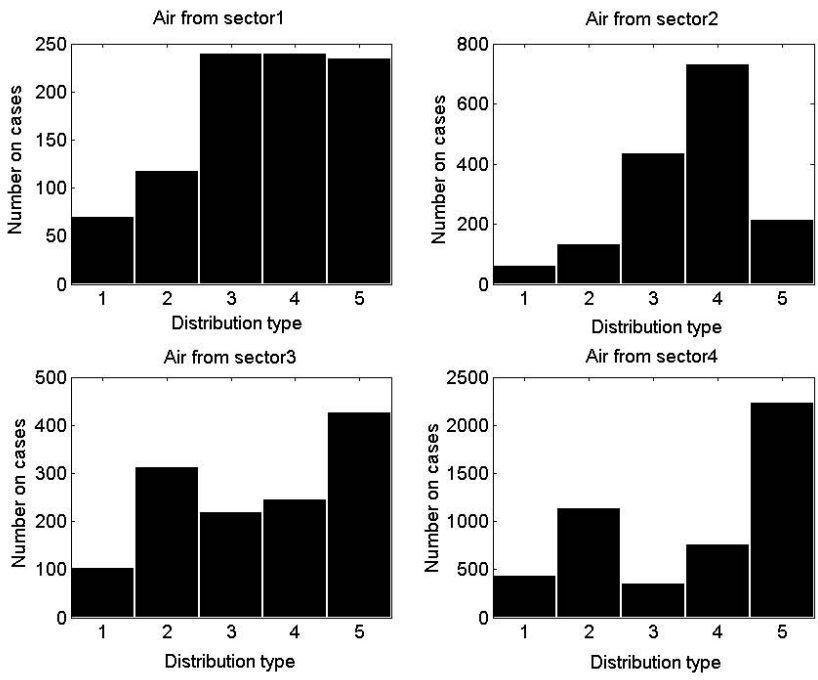

Fig. 8. Abundancy of the five distribution types in air masses coming from the four different sectors.

checked with independent CPC measurements (particle diameter $>10 \mathrm{~nm}$ ) running parallel with the DMPS system and a good agreement was found between the instruments.

The average and median number concentrations of all particles $\left(12-570 \mathrm{~nm}\right.$ in diameter) were $2030 \mathrm{~cm}^{-3}$ and $1390 \mathrm{~cm}^{-3}$, respectively. The concentrations at Mount Waliguan were higher than those measured in Europe, North
America and Japan at similar altitudes. The particle number concentrations reported in this study are more similar to those reported at several alpine sites at Indian Himalayas. Accumulation mode particle number concentrations were higher than those reported elsewhere at similar altitude, and are closer to those reported in planetary boundary layer at rural locations.

The particle number concentration seemed to peak at summer but, because of the lack of data, this feature could not be verified. When averaged over the different seasons individually, daily patterns in the particle number concentration emerged. The number concentration of nucleation mode particles (diameter $<21 \mathrm{~nm}$ ) increased in the afternoon between noon and around 17:00 Beijing time, and gradually decreased for the rest of the time. This increase was also seen in the Aitken mode some hours later during summer, but not during any of the other seasons. No clear daily patterns were found in the accumulation mode number concentration during any season. The daily patterns in nucleation and Aitken modes are probably a result of the new particle formation events in the area. There was no systematic pattern of changes between boundary layer and free tropospheric air in any season.

A trajectory analysis revealed that air masses coming from the east $\left(45^{\circ}-165^{\circ}\right)$ had, on average, higher particle number concentrations than those coming from other directions. These particles were mainly in the Aitken and accumulation mode. The portion of nucleation mode particles was highest 
in air masses coming from western desert areas (direction $270^{\circ}-315^{\circ}$ ). The Aitken to accumulation mode number concentration ratio was around 2.6-3.2 in all air masses, which indicated that most particles were produced within the last one or two days, rather than being transported from over large distances. The air masses coming from East to Mount Waliguan also typically originated from other sectors (mostly western sector), and had spent only the last day or two in the eastern sector.

These findings indicate that the site is probably not affected much by the atmospheric brown cloud over Southern and Eastern China (Ramanathan et al., 2007a) even when the air masses are coming from east. The high particle number concentrations in eastern air masses are more probably caused by anthropogenic pollution sources at shorter distances east of the station. The regional-scale aerosol formation seems to be intense, contributing to high particle number concentrations in other air masses as well. Both of these factors increase the summer time particle number concentration more than that of winter time, producing the seasonal pattern.

Acknowledgements. This work was supported by Tor and Maj Nessling foundation and by CMA-FMI bilateral cooperation project, the National Natural Science Foundation of China (Grant No. 40575063), National Basic Research Program of China (Grant No. 2006CB403703, 2006CB403701). The authors would also like to thank the Mount Waliguan staff for operating and maintaining the instruments at the station.

Edited by: G. Roberts

\section{References}

Aalto, P., Hämeri, K., Becker, E., Weber, R., Salm, J., Mäkelä, J. M., Hoell, C., O’Dowd, C. D., Karlsson, H., Hansson, H.C., Väkevä, M., Koponen, I. K., Buzorius, G. and Kulmala, M.: Physical Characterization of aerosol particles during nucleation events, Tellus B, 53, 344-358, 2001.

Bonasoni, P., Laj, P., Angelini, F., Arduini, J., Bonafe, U., Calzolari, F., Christofanelli, P., Decesari, S., Facchini, M. C., Fuzzi, S., Gobbi, G. P., Maione, A., Marinoni, A., Petzold, A., Roccato, F., Roger, J.-C., Sellegri, K., Sprenger, M., Venzac, H., Verza, G. P., Villani, P., and Vuillermoz, E.: The ABC-Pyramid Atmospheric Research Observatory in Himalaya for aerosol, ozone and halocarbon measurements, Sci. Total Environ., 391(2-3), 252-261, doi:10.1016/j.scitotenv.2007.10.024, 2008.

Brasseur, G. P., Orlando, J. J. and Tyndall, G. S.: Atmospheric Chemistry and Global Change, Oxford University Press, Oxford, UK, 654 pp., 1999.

Buck, A. L.: New equations for computing vapor pressure and enhancement factor, J. Appl. Meteorol., 20, 1527-1532, 1981.

Dal Maso, M., Sogacheva, L., Anisimov, M. P., Arshinov, M., Baklanov, A., Belan, B., Khodzher, T. V., Obolkin, V. A., Staroverova, A., Vlasov, A., Zagaynov, V. A., Lushnikov, A., Lyobovtseva, Y. S., Riipinen, I., Kerminen, V.-M., and Kulmala
M.: Aerosol particle formation events at two Siberian stations inside the boreal forest, Boreal. Env. Res. 13(2), 81-92. 2008a.

Dal Maso, M., Hyvärinen, A., Komppula, M., Tunved, P., Kerminen, V.-M., Lihavainen, H., Viisanen, Y., Hansson, H.-C. and Kulmala, M., Annual and interannual variation in boreal forest particle number and volume concentration and their connection to new particle formation, Tellus B, 60(4) 495-508, $2008 \mathrm{~b}$.

Diner, J. D., Ackerman, T. P., Anderson, T. L., Bösenberg, J., and collaborators: PARAGON. An integrated approach for characterizing aerosol climate impacts and environmental interactions, Bull. Amer. Meteor. Soc., 85, 1491-1501, 2004.

Gajananda, K., Kuniyal J. C., Momin, G. A., Rao, P. S. P., Safai, P. D., Tiwan, S., and Ali, K.: Trend of atmospheric aerosols over the north western Himalayan region, India, Atmos. Environ., 39, 4817-4825, 2005.

GAWSIS station information system, Mt Waliguan: http://gaw. empa.ch/gawsis/reports.asp?StationID=12, last accss: 26 June 2008.

Ghan, S. J. and Schwartz, S. E.: Aerosol properties and processes. A path from field and laboratory measurements to global climate models, Bull. Amer. Meteor. Soc., 88, 1059-1083, 2007.

Heintzenberg, J., Birmili, W., Theiss, D. and Yisilyakhov, Y.: The atmospheric aerosol over Siberia, as seen from the $300 \mathrm{~m}$ ZOTTO tower, Tellus B, 60, 276-285, 2008.

Hoffmann, J.: Twenty years of balloon-borne tropospheric aerosol measurements at Laramie, Wyoming, J. Geophys. Res., 98(D7), 12753-12766, 1993.

Keil, A. and Wendisch, M.: Bursts of Aitken mode and ultrafine particles observed at the top of continental boundary layer clouds, J. Aerosol Sci., 32, 649-660, 2000.

Komppula, M., Lihavainen, H., Hatakka, J., Aalto, P. P., Kulmala, M., and Viisanen, Y.: Observations of new particle formation and size distribution at two different heights and surroundings in subarctic area in northern Finland, J. Geophys. Res., 108(D9), 4295, doi:10.1029/2002JD002939, 2003.

Komppula, M., Lihavainen, H., Hyvärinen, A.-P., Kerminen, V.-M., Panwar, T. S., Sharma, V. P. and Viisanen, Y.: Physical properties of aerosol particles at a Himalayan background site in India, J. Geophys. Res., 114, D12202, doi:10.1029/2008JD011007, 2009.

Koutsenogii, P. K. and Jeanicke, R.: Number concentration and size distribution of atmospheric aerosol in Siberia, J. Aerosol. Sci., 25, 377-383, 1994.

Kulmala, M., Vehkamäki, H., Petäjä, T., Dal Maso, M., Lauri, A., Kerminen, V.-M., Birmili, W., and McMurry, P. H.: Formation and growth rates of ultrafine atmospheric particles: A review of observations, J. Aerosol Sci., 35, 143-176, 2004.

Kulmala, M., Kerminen, V.-M., Laaksonen, A., Riipinen, I., Sipilä, M., Ruuskanen, T. M., Sogacheva, L., Hari, P., Bäck, J., Lehtinen, K. E. J., Viisanen, Y., Bilde, M., Svenningsson, B., Larzridis, M., Tørseth, K., Tunved, P., Nilsson, E. D., Pryor, S., Sørensen, L.-L., Hõrrak, U., Winkler, P. M., Swietlicki, E., Riekkola, M.-L., Krejci, R., Hoyle, C., Hov, Ø, Myhre, G., and Hansson, H.-C.: Overview of BACCI (Biosphere-AerosolCloud-Climate Interactions) studies, Tellus B, 60, 300-317, 2008.

Kulmala, M. and Kerminen, V.-M.: On the formation and growth of atmospheric nanoparticles, Atmos. Res., 90, 132-150, 2008.

Laakso, L., Hussein, T., Aarnio, P., Komppula, M., Hiltunen, V., Viisanen, Y., and Kulmala, M.: Diurnal and annual charachteristics 
of particle mass and number concentrations in urban, rural and Arctic environments in Finland, Atmos. Environ., 37, 26292641, 2003.

Laakso, L., Grönholm, T., Kulmala, L., Haapanala, S., Hirsikko, A., Lovejoy, E. R., Kazil, J., Kurtén, T., Boy, M., Nilsson, E. D., Sogachev, A., Riipinen, I., Strattmann, F., and Kulmala, M.: Hotair balloon as a platform for boundary layer profile measurements during particle formation, Boreal Env. Res., 12, 279-294, 2007.

Lau, K.-M. and Kim, K.-M.: Observation relationship between aerosol and Asian rainfall and circulation, Geophys. Res. Lett., 33, L21810, doi:10.1029/2006GL027546, 2006.

Lelieveld, J., Crutzen, P. J., Ramanathan, V., Andreae, M. O., Brenninkmeijer, C. A. M., Campos, T., Cass, G. R., Dickerson, R. R., Fisher, H., De Gouw, J. A., Hansel, A., Jefferson, A., Kley, D., De Laat, A. T. J., Lal, S., Lawrence, M. G., Lobert, J. M., MayolBracero, O. L., Mitra, A. P., Novakov, T., Oltmans, S. J., Prather, K. A., Reiner, T., Rodhe, H., Scheeren, H. A., Sikka, D., and Williams, J.: The Indian Ocean Experiment: Widespread air pollution from South and Southeast Asia, Science, 291, 1031-1036, 2001.

Mönkkönen, P., Koponen, I. K., Lehtinen, K. E. J., Hmeri, K., Uma, R., and Kulmala, M.: Measurements in a highly polluted Asian mega city: observations of aerosol number size distribution, modal parameters and nucleation events, Atmos. Chem. Phys., 5, 57-66, 2005,

http://www.atmos-chem-phys.net/5/57/2005/.

Nakajima, T., Yoon S.-C., Ramanathan, V., Shi, G.-Y., Takemura, T., Higurashi, A., Takamura, T., Aoki, K., Sohn, B.-Y., Kim, S.-W., Tsuruta, H., Sugimoto, N., Shimizu, A., Tanimoto, H., Sawa, Y., Lin, N.-H., Lee, C.-T., Goto, D., and Schutgens, N.: Overview of the Atmospheric Brown Cloud East Asian Regional Experiment 2005 and a study of the aerosol direct radiative forcing in east Asia, J. Geophys. Res., 112, D24S91, doi:10.1029/2007JD009009, 2007.

Nishita, C., Osada, K., Matsunaga, K. and Iwasaka, Y.: Numbersize distributions of free tropospheric aerosol particles at Mt. Norikura, Japan: Effects of precipitation and air mass transportation pathways, J. Geophys. Res., 112, D10213, doi:10.1029/2006JD007969, 2007.

Nishita, C., Osada, K., Kido, M., Matsunaga, K. and Iwasaka, Y.: Nucleation mode particles in upslope valley winds at Mount Norikura, Japan: Implications for the vertical extent of new particle formation events in the lower troposphere, J. Geophys. Res., 113, D06202, doi:10.1029/2007JD009302, 2008.

Nyeki, S., Baltensperger, U., Colbeck, I., Jost, D. T., Weingartner, E., and Gäggeler H. W.: The Jungfrayjoch high-alpine research station $(3454 \mathrm{~m})$ as a background clean continental site for the measurement of aerosol parameters, J. Geophys. Res., 103(D6), 6097-6107, 1998a.

Nyeki, S., Li, F., Streit, N., Colbeck, I., Gäggeler, H. W., and Baltensperger, U.: The background aerosol size distribution in the free troposphere: An analysis of the annual cycle at high alpine site., J. Geophys. Res., 103(D24), 31749-31761, 1998b.

Oanh, N. T. K., Upadhuay, N., Zhuang, Y.-H., Hao, Z.-P., Murthy, D. V. S., Lestari P., Villarin, J. T., Chengchua, K., Co, H. X., Dung, N. T. and Lindgren, E. S.: Particulate pollution in six Asian cities: spatial and temporal distributions, and associated sources, Atmos. Environ., 40, 3367-3380, 2006.

Pandey, J. S., Kumar, R., and Devotta, S.: Health risks of NO2, SPM and SO2 in Delhi, India, Atmos. Environ., 39, 6868-6874, 2005.

Paris, J.-D., Arshinow, M. Y., Ciais, P., Belan, B. D., and Nédélec, P.: Large-scale aircraft observations of ultra-fine particle concentrations in the remote Siberian troposphere: new particle formation studies, Atmos. Environ., 43, 1302-1309, 2009.

Pathirana, A., Herath, S., Yamada, T., and Swain, D.: Impacts of absorbing aerosols on South Asian rainfall. A modelling study, Climatic Change, 85, 103-118, 2007.

Ramanathan, V., Li, F., Ramana, M. V., Praveen, P. S., Kim, D., Corrigan, C. E., Ngyen, H., Stone, E. A., Schauer, J. J., Carmichael, G. R., Adhikary, B., and Yoon, S. C.: Atmospheric brown clouds: Hemispherical and regional variations in longrange transport, absorption, and radiative forcing, J. Geophys. Res., 112, D22S21, doi:10.1029/2006JD008124, 2007a.

Ramanathan, V., Ramana M. V., Roberts, G., Kim, D., Corrigan, C., Chung, C., and Winker, D.: Warming trends in Asia amplified by brown cloud solar absorption, Nature, 448, 575-579, 2007b.

Remer, L. A., Kleidman, R. G., Levy, R. C., Kaufman, Y. J., Tanre, D., Mattoo, S., Martins, J. V., Ichoku, C., Koren, I., Yu, H., and Holben, B. N.: Global aerosol climatology from MODIS satellite sensors, J. Geophys. Res., 113, D14S07, doi:10.1029/2007JD009661, 2008.

de Reus, M., Ström, J., Curtius, J., Pirjola, L., Vignati, E., Arnold, F., Hansson, H.-C., Kulmala, M., Lelieveld, J., and Raes, F.: Aerosol production and growth in the upper free troposphere, J. Geophys. Res., 105(D20), 24751-24762, 2000.

Shaw, G. E.: Aerosols at a mountaintop observatory in Arizona, J. Geophys. Res., 122, D07206, doi:10.1029/2005JD006893, 2007.

Stohl, A., Wotawa, G., Seibert, P., and Kromp-Kolb, H.: Interpolation errors in wind fields as a function of spatial and temporal resolution and their impact on different types of kinematic trajectories, J. Appl. Meteor., 34, 2149-2165, 1995.

Tobo, Y., Zhang, D., Iwasaka, Y., and Shi, G.: On the mixture of aerosols and ice clouds with dynamic and constituent fields over the Tibetan plateau: Results of a balloon flight in the summer of 1999, Geophys. Res. Lett., 34, L23801, doi:10.1029/2007GL031132, 2007.

Venzac, H., Sellegri, K., Laj, P., Villani, P., Bonasoni, P., Marinoni, A., Cristofanelli, P., Calzolari, F., Fuzzi, S., Facchini, M.C., Vuillermoz, E., and Verza, G. P.: High frequency new particle formation in the Himalayas, Proc. Natl. Acad. Sci. USA 105(41), 15666-15671, doi/10.1073/pnas.0801355105, 2008.

Wang, T., Wong, H. L. A., Tang, J., Ding, A., Wu, W. S., and Zhang, X.-C.: On the origin of surface ozone and reactive nitrogen observed at a remote mountain site in the northeastern QinghaiTibetan Plateau, western China, J. Geophys. Res, 111, D08303, doi:10.1029/2005JD006527, 2006.

Weber, R. and McMurry, P.: Fine particle size distributions at the Mauna Loa observatory, Hawaii, J. Geophys. Res., 101(D9), 14767-14775, 1996.

Wehner, B., Birmili, W., Ditas, F., Wu, Z., Hu, M., Liu, X., Mao, J., Sugimoto, N., and Wiedensohler, A.: Relationships between submicrometer particulate air pollution and air mass history in Beijing, China, 2004-2006, Atmos. Chem. Phys., 8, 6155-6168, 2008,

http://www.atmos-chem-phys.net/8/6155/2008/.

Weingartner, E., Nyeki, S., and Baltensperger, U.: Seasonal and diurnal variation of aerosol size distributions $(10<\mathrm{D}<750 \mathrm{~nm})$ at a high-alpine site (Jungfaujoch $3580 \mathrm{~m}$ a.s.l.), J. Geophys. Res., 
104(D21), 26809-26820, 1999.

Yu, H., Kaufman, Y. J., Chin, M., Feingold, G., Remer, L. A., Anderson, T. L., Balkanski, Y., Bellouin, N., Boucher, O., Christopher, S., DeCola, P., Kahn, R., Koch, D., Loeb, N., Reddy, M. S., Schulz, M., Takemura, T., and Zhou, M.: A review of measurement-based assessments of the aerosol direct radiative effect and forcing, Atmos. Chem. Phys., 6, 613-666, 2006, http://www.atmos-chem-phys.net/6/613/2006/.

Zhou, L. X., Tang, J., Ernst, M. K. and Worthy, D. E. J.: Continuous measurements of baseline atmospheric carbon monoxide in western China, Environ. Sci, 22(3), 1-5, 2001.
Zhou, L. X., Tang, J., Wen, Y., Yan, P. and Zhang, X.-C.: The impact of local wind and long-range transport on the continuous carbon dioxide record at Mount Waliguan, China, Tellus 55B, 145-158. 2003.

Zhou, L. X., Worthy, D. E. J., Lang, P. M., Ernst, M. K., Zhang, X. C., Wen, Y. P., and Li, J. L.: Ten years of atmospheric methane observations at a high elevation site in Western China, Atmos. Environ., 38, 7041-7054, 2004. 